OPEN ACCESS

Edited by:

Lars Nitschke,

University of Erlangen Nuremberg,

Germany

Reviewed by:

Ronald B. Corley,

Boston University, United States

Julia Jellusova,

TU München, Germany

Dirk Mielenz,

University of Erlangen Nuremberg,

Germany

*Correspondence:

Thierry Fest

thierry.fest@univ-rennes1.fr

Specialty section: This article was submitted to B Cell Biology,

a section of the journal

Frontiers in Immunology

Received: 24 February 2021

Accepted: 12 April 2021

Published: 29 April 2021

Citation:

Lemarié $M$, Chatonnet $F$, Caron $G$ and Fest T (2021) Early Emergence of Adaptive Mechanisms Sustaining Ig Production: Application to Antibody Therapy.

Front. Immunol. 12:671998. doi: 10.3389/fimmu.2021.671998

\section{Early Emergence of Adaptive Mechanisms Sustaining Ig Production: Application to Antibody Therapy}

\author{
Maud Lemarié $^{1}$, Fabrice Chatonnet ${ }^{1,2}$, Gersende Caron ${ }^{1,2}$ and Thierry Fest ${ }^{1,2 *}$ \\ 1 Université de Rennes 1, INSERM, Établissement Français du Sang de Bretagne, UMR_S1236, Rennes, France, \\ 2 Laboratoire d'Hématologie, Pôle de Biologie, Centre Hospitalier Universitaire, Rennes, France
}

Antibody therapy, where artificially-produced immunoglobulins $(\mathrm{lg})$ are used to treat pathological conditions such as auto-immune diseases and cancers, is a very innovative and competitive field. Although substantial efforts have been made in recent years to obtain specific and efficient antibodies, there is still room for improvement especially when considering a precise tissular targeting or increasing antigen affinity. A better understanding of the cellular and molecular steps of terminal B cell differentiation, in which an antigen-activated B cell becomes an antibody secreting cell, may improve antibody therapy. In this review, we use our recently published data about human B cell differentiation, to show that the mechanisms necessary to adapt a metamorphosing $B$ cell to its new secretory function appear quite early in the differentiation process i.e., at the preplasmablast stage. After characterizing the molecular pathways appearing at this stage, we will focus on recent findings about two main processes involved in antibody production: unfolded protein response (UPR) and endoplasmic reticulum (ER) stress. We'll show that many genes coding for factors involved in UPR and ER stress are induced at the preplasmablast stage, sustaining our hypothesis. Finally, we propose to use this recently acquired knowledge to improve productivity of industrialized therapeutic antibodies.

Keywords: UPR, ER stress, B cell differentiation, mAbs, RNA-seq

\section{ON THE ROAD TO BECOME AN INGENIOUS SECRETED- ANTIBODY FACTORY: DIFFERENTIATION STEPS FROM B TO PLASMA CELL}

Plasma cells (PCs) secrete huge amount of immunoglobulin molecules (Igs) subsequently to antigen entry into the body. Before becoming high-affinity antibody secreting cells (ASCs), B cells undergo several steps of differentiation. First, inside the bone marrow, precursor B cells edit a B-cell receptor (BCR) (or surface-attached IgM, an-antigen specific Ig of the first line of defence with poor affinity towards the antigen). At this point, they produce Ig but only intended to be transmembrane receptors. Naive B cells (NBCs) are in a resting state in peripheral blood or secondary lymphoid organs until their activation by a foreign antigen. Once activated by circulating antigens, NBCs reach a secondary 
lymphoid organ and move towards the $\mathrm{B}$ : $\mathrm{T}$ interface where they receive help from specialized CD4+ T cells called follicular helper $\mathrm{T}$ cells (Tfh) via efficient B: T synapses (1-3). B cells need interaction with several co-activators, including CD40L and the delivery of cytokines including IL-21 and IL-4, to undergo their differentiation into fully mature effectors. The terminal steps of the differentiation occur in a microanatomical specialized area of secondary lymphoid organs called germinal centers (GCs) which are created by B cells themselves in response to BCL6 expression. In this context, IL-21 represents the main upstream cytokine responsible for BCL6 maximal expression and GCs maintenance (4). GCs are organized into two separated territories - called light zone and dark zone - between which the B cell continuously moves until reaching a high affinity for targeted antigens (1-3). At first, B cells proliferate in the dark zone where cells undergo AIDdriven somatic hypermutation (SHM) of variable regions of their Ig gene loci. The second step takes place into the light zone where $\mathrm{B}$ cell clones carrying a modified variable region of Ig are tested for its antigen affinity by follicular dendritic cells with the help of Tfh cells. Clonal B cells go through this step with 4 different outcomes based on the strength of BCR signal (antigen affinity) and the amount of Tfh help received: (i) a low-affinity and no help leads to apoptosis of the clone; (ii) mid-affinity and low Tfh help leads to the formation of a long-lived memory cell, (iii) higher affinity and $\mathrm{T}$ cell help leads to another round of SHM in the dark zone and (iv) highest levels of both signal leads to the differentiation into a long-lived plasma cell (PC) $(2,3,5)$. This B cell maturation is completed by the Ig class-switch recombination (CSR), allowing cells to produce and secrete IgM, IgG, IgE or IgA, each class offering specific functions to adapt the antibody response to the context.

In our lab, we developed and standardized an in vitro model system of human NBCs differentiation into plasmablasts (PBs) (Figure 1). Starting from blood donor buffy coat we purify NBCs and then culture them with IL-2, CD40L, CpG and anti-IgM Fab'2 in order to activate cells via a transcriptional burst (6). As soon as day-1, B cells are fully activated and referred hereafter as day-1 ActB. Beyond day-4 (day-4 ActB), culture conditions are modified and cells maintained only with IL-2, IL-4 and IL-10 stimulation for 2 or 3 additional days in order to complete the PB differentiation. We showed recently that committed B cells that differentiate into PBs present an extinction of both IL-4/STAT6 signaling and CBLB ubiquitin ligase expression, concomitant to IRF4 induction (7). As a surrogate marker of this commitment, membrane surface expression of CD23 disappears due to IL-4/STAT6 extinction. We showed that day-5 CD23- post-ActB cells contain precursors of plasmablasts (pre-PBs) which present the capacity to enter the cell cycle, while the $\mathrm{CD} 23^{+}$counterparts are unable to differentiate and stay in an activated state $(7,8)$. After nearly 7-8 days of culture, some PBs start to express the PC-specific CD138 marker which points out the generation of early PCs. PB and PC differentiated in vitro secrete high amounts of Igs; they display morphological and transcriptomic features of their in vivo counterpart and represent an useful tool to explore normal human PB and PC biology (8-10).

While becoming a PC and therefore fully efficient for Ig secretion, cells experience massive organelles modifications including membrane amplification and trafficking. The endoplasmic reticulum structure reaches its maximum of protein production during this stage (11) and cells are subject to an intensive and continuous stress that needs to be controlled to escape from cell death.

\section{EARLY APPEARANCE OF ADAPTIVE MECHANISMS TO HIGH THROUGHPUT IG SECRETION}

\section{General Mechanisms of ER Stress and Unfolded Protein Response (UPR)}

In every tissue, cells continuously produce proteins in their cytoplasm to meet their needs and to respond to

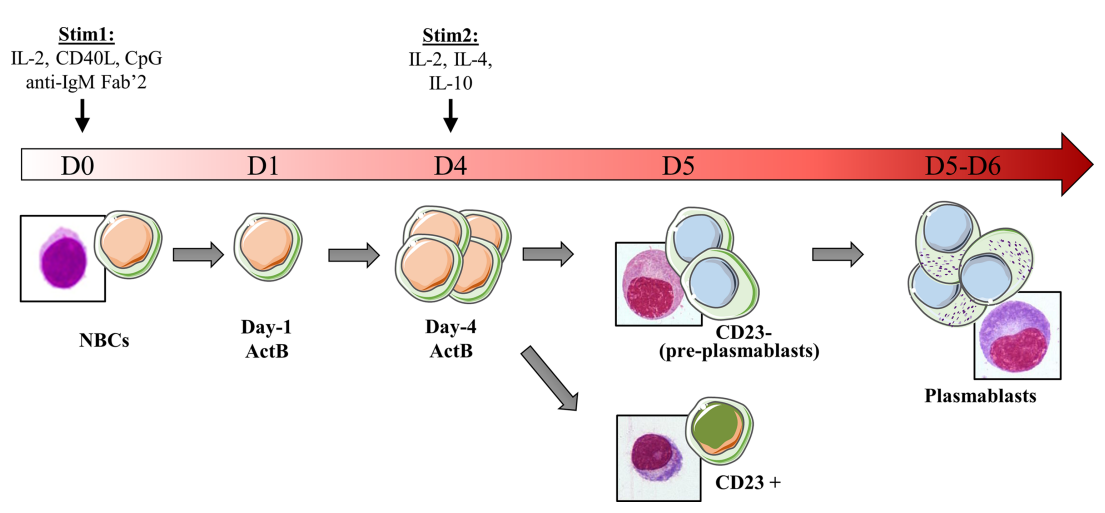

FIGURE 1 | Schematic representation of the in vitro model of B cells differentiation used in our laboratory. Peripheral NBCs from blood donors are stained with a celltracer then stimulated with IL-2, CD40L, CpG and anti-lgM Fab'2. Day-1 activated cells are referred as day-1 ActB. After 4 days, activated B cells that have proliferated (Day-4 ActB) are selected according cell-tracer dilution and stimulated with IL-2, IL-4 and IL-10 to induce their differentiation into plasmablasts. The day after (D5), three populations are detected: (i) CD23+ cells that are stuck in an activated state and unable to differentiate, (ii) CD23- population, containing precursors of plasmablasts (pre-PB) which give rise to (iii) differentiated plasmablasts (PB). The increase in the cytoplasm/nucleus ratio, characteristic of the development of the lg production machinery in PB, is early detected in the pre-PB stage. RNA-seq data are available for NBC, Day-1 ActB, Day-4 ActB, CD23+, CD23- and PB subsets. 
microenvironment signals. Igs are part of the transmembrane and secreted proteins. After being transcribed, mRNA is pushed to the surface of the endoplasmic reticulum (ER) to be processed by the ER-attached ribosomes and translated into the ER lumen. As the translation occurs in the ER, proteins enter the lumen in their misfolded form. From here, Igs produced in naive B cells start their journey through multiple organelles in order to be well-processed and then bound to the membrane. After antigen activation, IgGs that are produced in $\mathrm{PBs} / \mathrm{PCs}$ are aimed to be secreted outside of the cell.

After antigen encounter and B cell differentiation into PC, a metabolic switch occurs and a sharp increase in nutrient uptake is necessary to meet the growing need (reviewed in (12)). Ig processing is overwhelmed into the ER lumen, leading to an unfolded and misfolded protein (hereafter designated un/ misfolded protein) rate increase and an ER high-stress state. The unfolded protein response (UPR) is then engaged in these cells to meet the increasing needs for protein processing, folding and secretion, and to protect them from apoptosis. Three well-characterized UPR axes have been described as involved in ER stress response: (i) inositol-requiring transmembrane kinase/endonuclease $1 \alpha$ (IRE1 $\alpha) / \mathrm{X}$-box binding protein (XBP) - 1, (ii) protein kinase RNA-like endoplasmic reticulum kinase (PERK) and (iii) activating transcription factor 6 (ATF6) pathways $(13,14)$. In resting conditions, the ATPase Ig-binding protein $(\mathrm{BiP})$ - a resident-ER chaperone - binds to each of them. Stress signals then lead to a BiP UPR first-line of response to ensure activation of ER transmembrane IRE1 $\alpha$, PERK and ATF6 elements. Indeed, BiP dissociates from IRE1 $\alpha$ and PERK proteins to release them and then binds to un/misfolded proteins (15). Importantly, BiP association/ dissociation cycle with IRE1 $\alpha$ and PERK is governed by an ADP-ATP cycle. ATP-bound BiP preferentially binds to ER transmembrane elements (16). When ER stress is increasing, DnaJ-like co-factors (ERdj) bind to un/misfolded proteins and accompany their transfer to the ATP-bound BiP, leading subsequently to ATP hydrolysis $(17,18)$. As a consequence, BiP dissociates from ER elements and then associates with un/ misfolded proteins under its ADP-binding state, stably sequestering clients to prevent aggregation in the ER lumen and accompanying for folding $(18,19)$. BiP-clients complex dissociation, induced by Nucleotide Exchange Factors (NEF) which remove $\mathrm{ADP}$ from $\mathrm{BiP}$, is then required to properly complete folding process and secretion. BiP consequently returns to its initial position with ER elements, meaning that ER stress is under control $(20,21)$. ATF6 is also released from BiP during ER stress (22) but needs an additional step to be fully activated. Hence, the released ATF6 is then cleaved in the Golgi apparatus by Site- 1 and Site- 2 proteases (encodes by MBTPS1 and MBTPS2, respectively) before being translocated back to the nucleus to induce the expression of UPR genes such as $X B P 1$ (23-26) (Figure 2).

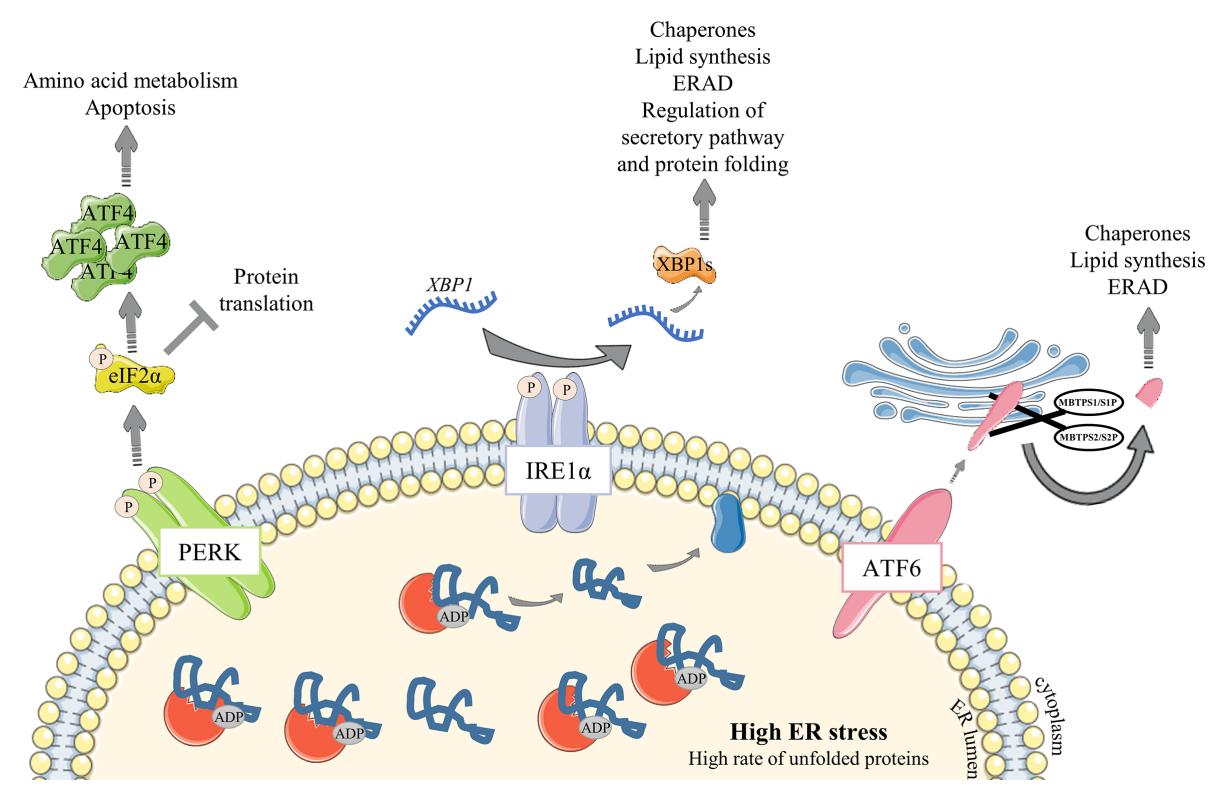

FIGURE 2 | Overview of the UPR signaling pathway under ER stress conditions. Unfolded Protein Response is engaged to respond to increasing amount of proteins in the ER. (1) The ER-resident chaperone BiP binds to unfolded and misfolded proteins and consequently releases the sequestrated IRE1 $\alpha$, PERK and ATF6 ER sensors, leading to their activation following (i) dimerization and auto-phosphorylation of IRE1 $\alpha$ and PERK elements or (ii) MBTPS1/S1P and MBTPS2/S2P - mediated cleavage of ATF6 $\alpha$ in the Golgi apparatus. Activated ATF6 $\alpha$ then translocates into the nucleus and upregulates chaperones expression and factors involved in lipid synthesis and ERAD. Activated PERK phosphorylates elF2 $\alpha$ which represses global protein translation except for ATF4 whose translation is enhanced. ATF4 then upregulates amino acid metabolism and apoptosis. IRE1 $\alpha$, via XBP-1 transcription factor, leads to a broader range of responses with upregulation of many factors including chaperones and those important for lipid synthesis and ERAD. IRE1 $\alpha$ regulates as well the factors important for protein folding and secretory functions. Particularly, XBP1 mRNA requires IRE1 $\alpha$ to be spliced and efficient as a transcription factor. 


\section{Early Appearance and Temporal Regulation of ER Stress and UPR Factors}

ER stress responses seem to be engaged well before PCs massively produce antibodies. A preparation to morphological and genomic modifications that NBCs undergo to become ASCs is probably needed. During B cell differentiation, BLIMP-1 (encoded by PRDM1), the major regulator of the antibodysecretory function of PCs, represses the B cell identity transcriptional program including genes encoding for BCL6 and PAX5 (27), and enhances XBP1 expression (28). Activation of this latter factor is one of the most important events and is maintained essentially by BLIMP-1. Interestingly, BLIMP-1 positively controls the activity of mammalian target of rapamycin (mTORC1) (29), which is described as a key metabolic factor since it controls proteins, nucleotides and lipids synthesis (30). mTORC1 has also been well characterized in B cell development $(31,32)$ but its role in ER stress has emerged only in the last decade with a few studies showing its importance for a sustainable Ig production. mTORC1 inhibition in mature murine PCs leads to a decrease in serum IgM and IgG levels and a failure to induce $\mathrm{BiP}$ protein expression $(33,34)$. More recently, mTORC1 was defined as a precocious factor in the UPR response to Ig production and secretion. In fact, two separated studies unveiled crucial aspects of mTORC1 function in murine PCs. Double knock-out of XBP-1 and TSC1, a mTOR inhibitor, leads to an increase of Ig production and the differentiation into PCs was maintained even in absence of XBP-1 (33). These results suggest the existence of an alternative UPR response independent of the IRE1 $\alpha / \mathrm{XBP}-1$ and ATF6 pathways. Additional studies indicate that UPR-, protein production- and secretion-affiliated gene expressions such as Hspa5, Pdia6, Ero1l, encoding respectively for BiP, for a protein disulfide isomerase and for an ER-resident oxidase, increased in activated B cells dependently of mTORC1. Interestingly, this upregulation is observed well before the activation of BLIMP1-dependent PC program and Xbp1 gene expression in mice (35). RNA-seq data obtained throughout our in vitro differentiation model of human B cells (7) support these results and show an UPR response well before cells are secreting antibodies. Hence, bio-informatic analyses of the RNA-seq dataset segregated genes linked to UPR by GO annotations into 4 clusters according to gene expression modifications during the differentiation steps: 1) stable from NBCs to PB stage; 2) upregulated as early as the day-1 ActB stage, 3) downregulated right after $\mathrm{B}$ cell activation, and 4) upregulated in pre- $\mathrm{PB}$ and maintained in $\mathrm{PBs}$ (Figure $\mathbf{3 A}$ ). Indeed, the comparison between NBCs, day-1 ActB, day-4 ActB, post$\mathrm{ActB}$, pre-PB cells, and $\mathrm{PB}$ cells shows that UPR-affiliated genes seem to be only partially influenced by the XBP-1 and PRDM1 expression levels. Since cluster 4 includes XBP-1, IRE1 $\alpha$ and ATF $6 \alpha$ factors, we hypothesized that UPR-associated genes specifically upregulated in pre-PB are IRE1 $\alpha / \mathrm{XBP}-1$ - or ATF6dependent which is not the case for genes from cluster 2 . The main functions associated with each cluster were then evaluated by the DAVID pathway enrichment software in order to find differences between ER stress response governed or not by
IRE1 $\alpha /$ XBP-1 or ATF6. Thus, genes from cluster 4 whose expression is specifically upregulated in Pre-PB and $\mathrm{PB}$ stages are mainly associated with IRE1 $\alpha$ - and ATF6- mediated UPR, protein folding and transport, and apoptosis inhibition. For genes involved in cluster 2 whose expression appears as soon as day-1 of the culture, they are mainly associated with ER to Golgi vesicle-mediated transport, ER stress suppression and IRE1 $\alpha$-mediated UPR (a few genes compared to cluster 4). Overall, both UPR and ER stress responses are activated early in $B$ cells engaged in PC differentiation and in at least two separate phases with different molecular requirements.

\section{A Specific Inhibition of the PERK Pathway Throughout B Cell Differentiation}

In contrast to insulin-secreting pancreas cells (36-38) and collagen-secreting chondrocytes (39), Ig secretion is described as using a PERK-independent ER stress response (40-42). In our in vitro model, EIF2AK3 (which encodes PERK itself) but also well-characterized DDIT3 (also known as CHOP) and ATF4, both pro-apoptotic PERK target genes, are all included in cluster 3. Interestingly, when the gene expressions in ActB and $\mathrm{PB}$ populations are compared to NBCs we noticed that in addition to EIF2AK3 and ATF4, other specific genes of the PERK pathway such as ATF3 and PPP1R15A are part of the cluster 3 (Figure 3A and Table S1). Their expressions are 2 to 10 times higher in NBCs compared to the more mature stages (Figure 3B). In contrast, the IRE1 $\alpha /$ ATF6 target gene, HSPA5 (from cluster 4) maintains high levels of expression from NBC to ActB stages and even increases its expression (by more than 3 times) at pre-PB stage (Figures 3B). Altogether, these data show that PERK-pathway gets inactivated as soon as NBCs are stimulated and remains inhibited in PC.

Characterization of the factors involved in the suppression of the PERK pathway during PC differentiation has long been elusive. However, two recent studies demonstrated the role of UFBP1 (Ufm1 binding protein 1; issued from the gene DDRGK1 presents in cluster 2) in this process. Indeed, UFBP1-mediated ufmylation of IRE $1 \alpha$ protein protects from IRE $1 \alpha$ degradation, leading to its stabilization and the suppression of the PERK pathway (43). In addition, the UFBP1-mediated suppression of PERK leads to the active promotion of PC differentiation and therefore ER expansion (44). Since the expression of DDRGK1 occurs in cluster 2 in our in vitro model, we speculate that UFBP1-mediated PERK inhibition is primarily IRE1 $\alpha / \mathrm{XBP}-1$ and ATF6 independent (Figures 3, 4 and Table S1). However, $D D R G K 1$ expression increases slightly in pre-PB and $\mathrm{PB}$ populations suggesting that a delayed IRE1 $\alpha / \mathrm{XBP}-1$ and ATF6 effect may exist and participate in $D D R G K 1$ expression at latter stages of differentiation.

The PERK pathway is also actively suppressed by the P58 ${ }^{\mathrm{IPK}}$ protein in many cell types. Mechanistically, $\mathrm{P} 58^{\mathrm{IPK}}$ binds directly to the kinase domain of PERK, which impedes its activity and further activation of its targets (45). P58 ${ }^{\mathrm{IPK}}$ is encoded by DNAJC3, a member of the DnaJ family acting downstream of the ATF6 and IRE1 $\alpha /$ XBP-1 pathways (28, 45-50). Although no clear evidence exist so far for its role in B cells, some studies 


\section{A}

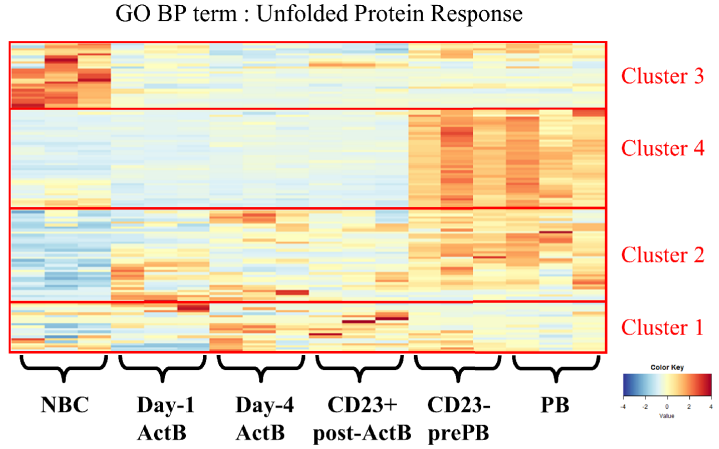

B
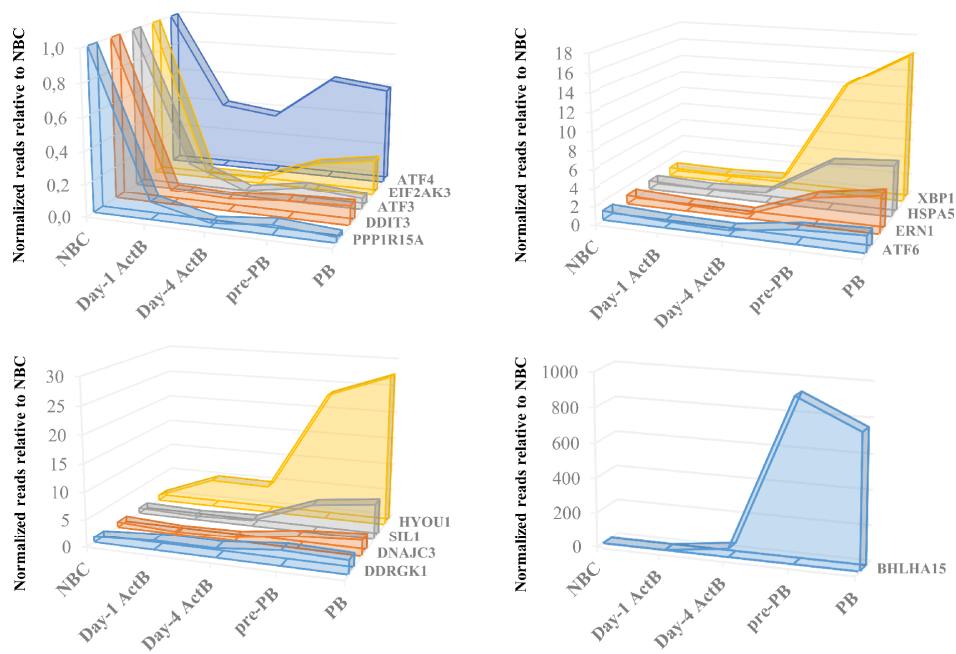

FIGURE 3 | Unfolded protein response is temporally regulated during the transition from naive B cells to plasmablasts. (A) Genes belonging to the Gene Ontology Biological Processes term "Unfolded Protein Response" were selected and their expression in our RNA-seq data was submitted to an unsupervised hierarchical clustering analysis. The resulting heatmap is shown here, delineating four different expression clusters: (1) stable expression, (2) genes upregulated from Day-1, (3) genes upregulated in NBC and (4) genes upregulated in Pre-PB and PB. (B) Means of normalized reads obtained from 3 different experiments at Day-1 ActB, Day-4 ActB, pre-PB and PB stages were compared to the NBC counterpart, whose mean is reduced to 1. Left upper panel shows genes related to the PERK pathway. Right upper panel shows genes related to the IRE1 $\alpha$ and ATF6 pathways and lower panels show potential genes which are either implicated (i) in the PERK regulation or (ii) in endoplasmic reticulum modifications related to stress. All of the selected genes are addressed in this review.

showed that $\mathrm{p} 58^{\mathrm{IPK}}$ protein expression increased rapidly after stimulation of murine B cells with LPS $(41,42)$ or CpG $(35)$, while the expression of PERK downstream targets decreased. In our model of human B cell differentiation, the expression of DNAJC3 increases strongly in cluster 4 in pre-PB and $\mathrm{PB}$ populations compared to ActB cells. This is in agreement with Gaudette et al. study in mice (35), which suggested that P58 ${ }^{\mathrm{IPK}}$ could partially contribute to the inhibition of the PERK pathway in ASCs, as soon as in the pre-PB stage (Figures 3, 4 and Table S1).

Similarly, SIL1, a nucleotide exchange factor, could represent another potential inhibitor of PERK since the SIL1 knockdown in HeLa cells showed an activation of the PERK pathway (51). In our model, SIL1 expression was strongly induced in pre-PB and $\mathrm{PB}$ (around 5-fold increase) compared to the earlier differentiation stages. Although SIL1 does not belong to the GO term UPR in Biological Processes (BP), we found it in the
RE Cellular Component (CC) annotation. A similar temporal clustering of our RNA-seq data performed on genes of this GO term showed that SIL1 belongs to a cluster of genes overexpressed specifically in pre-PBs and PBs (GO CC: RE; cluster 3) (Figures 3B, S1 and Table S2). Interestingly, SIL1 has been described as a co-chaperone of $\mathrm{BiP}$ required for the release of BiP-clients in the ER lumen $(20,21)$ after sequestration with BiP. However, the knockdown mouse model of Ichhaporia et al. demonstrated that SIL1 was unnecessary for the release of BiP from un/misfolded Ig and for subsequent production of Ig (52). Recently, ChIP-sequencing data done in human PBs (GSE142493 (53);) revealed an enrichment of XBP-1 in SIL1 promoter, suggesting a potential role of SIL1 in cell differentiation. This result, together with the HeLa data described above and our model of $\mathrm{B}$ cell differentiation strongly suggests that SIL may play a role in the inhibition of the PERK pathway in human ASCs (Figure 4). In addition, 


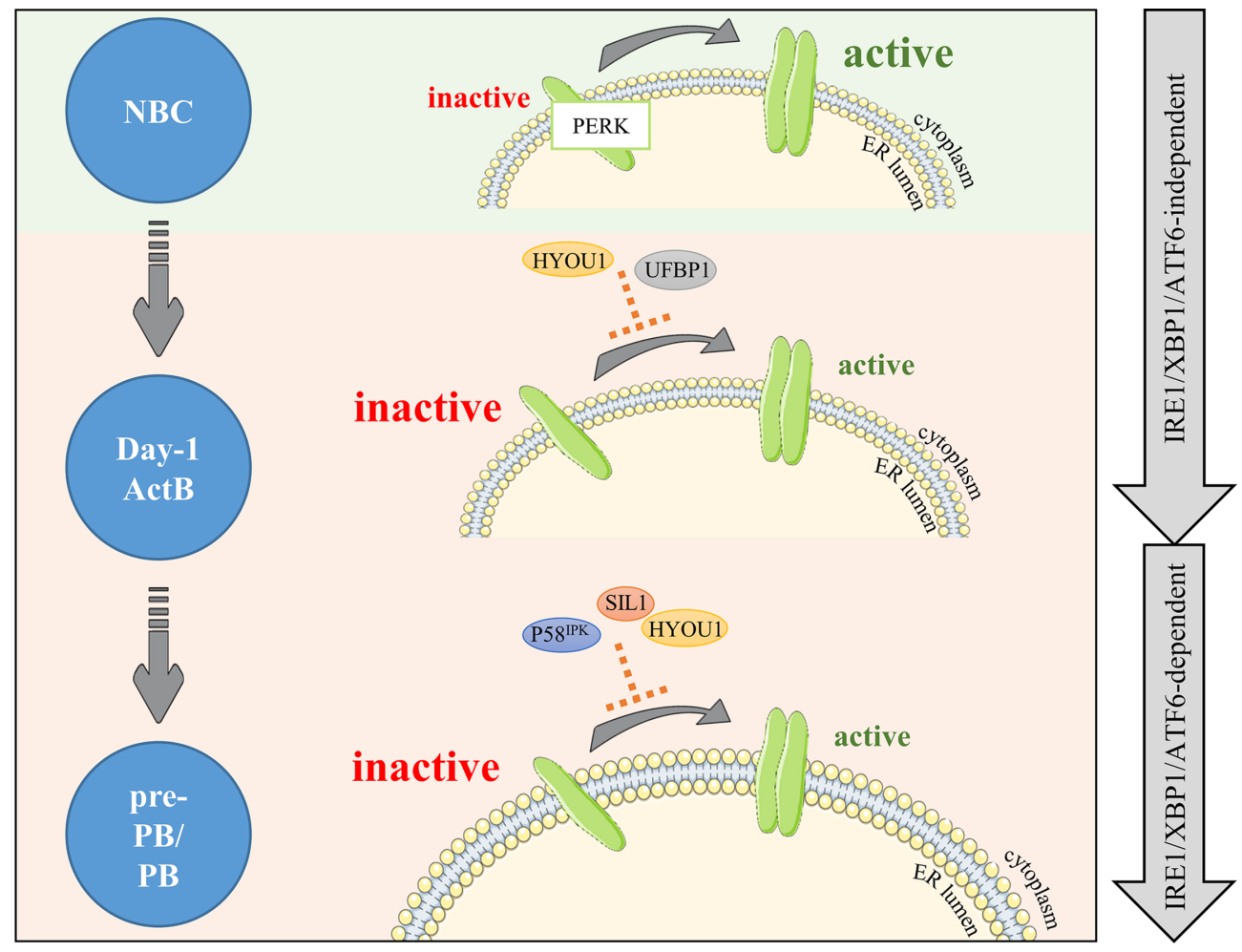

FIGURE 4 | PERK is negatively regulated right after B cell activation and maintained under negative control during differentiation. PERK signaling is upregulated in NBCs (light green background). In activated B cells, PERK needs to be dampened by factors limiting PERK activity (light orange background). Our RNA-seq analysis combined with literature emphases on two new potential negative factors: HYOU1 and UFBP1. Then, differentiation (pre-PB/PB) involves important changes including increased production of lg, which critically increases ER stress and risks of apoptosis; hence, PERK signaling repression needs to be reinforced. Factors potentially involved in this control are part of the ADP/ATP BiP regulation cycle: the DnaJ protein P58 ${ }^{\mathrm{IPK}}$ and the nucleotide exchange factors SIL1 and HYOU1. The first wave of negative control is IRE1 $\alpha /$ XBP-1/ATF6-independent and the second wave is IRE1 $\alpha /$ XBP-1/ATF6-dependent (right gray arrows).

HYOU1 (also known as ORP150) which is another nucleotide exchange factor for BiP, can substitute for SIL1 (54-56) and has been described in the literature as a cyto-protective factor against ER stress $(57,58)$. In our system, HYOU1 (which, unlike SIL1, is included in the GO BP UPR term) belongs to the cluster 4 and its expression is (i) higher than for SIL1 and (ii) strongly upregulated in pre-PB and $\mathrm{PB}$ stages (Figure $\mathbf{3}$ and Table S1). Then, given that HYOU1 can substitute for SIL1 in its functions, HYOU1 could represent an alternative factor of suppression of PERK, active in the last stages of B cell differentiation (Figure 4).

Taken together, these data provide support to a better understanding of PERK suppression in ASCs. Consistent with previous studies $(35,42)$, we found that the PERK pathway is inhibited early in the process of B cell differentiation by the specific repression of some of its genes. Two phases of repression seem to exist: (i) a strong first wave of repression, IRE1 $\alpha / \mathrm{XBP}-1$ and ATF6 independent which appears right after NBC activation, and (ii) a second wave, dependent on IRE1 $\alpha / \mathrm{XBP}-1$ and ATF6 occurring when Ig production is at its highest level (Figure 3B). ASCs are constantly in a state of prolonged and elevated ER stress and therefore at a constant risk of apoptosis.
Even though the implication of apoptosis mediated by the PERK and IRE1 $\alpha / \mathrm{XBP}-1$ pathways in the resolution of acute ER stress is controversial $(31,59-70)$, prolonged PERK signaling promotes apoptosis in contrast to a sustained IRE1 $\alpha$ response which improves cell survival (71). Therefore, in order to achieve successful antibody secretion in ASCs, it appears that PERK signaling needs to be restricted. In addition, previous studies suggested that while PERK could be partially activated in stimulated B cells, the subsequent signal appears not to be sufficient to induce target genes $(41,42)$.

Interestingly, the expression pattern of HYOU1 is bimodal with the first and second peak of expression corresponding, respectively, to the first and second wave of PERK inhibition (Figures 3B and 4). Since XBP-1 and ATF6 have been reported as critical inductors of Hyoul expression in murine B cells and fibroblasts, respectively, we hypothesise that both factors may contribute to HYOU1-mediated PERK inhibition in the late stage of B cell differentiation $(35,49)$. However, to date, no mechanism of action has been highlighted regarding either HYOU1 or SIL1 suppression of PERK pathway and further investigations are required to clarify this point. Altogether, HYOU1, in addition to provide ER stress protection (72-74), 
may exhibit critical repressor control of PERK in ASCs together with UFBP1 and P58 ${ }^{\mathrm{IPK}}$.

\section{Focus on MIST1, a Factor Involved in IRE1 $\alpha / X B P-1 / A T F 6$ Response}

In the literature, XBP-1 appears to be a central factor governing the UPR response in PC differentiation and Ig secretion. To be actively efficient under ER-stress conditions, XBP-1 mRNA needs to be spliced by IRE1 $\alpha$ which is previously released from $\mathrm{BiP}$ and then activated after auto-phosphorylation (75). Among potential XBP-1 target genes identified in murine PCs, MIST1 (encoded by Bhlha15) is a factor which has already been documented as important in secretory functions of some cells (76-80). Bhlha15 promoter is bound by XBP-1 in murine PCs (76) and its expression is under XBP-1 dependence in several cell types including PCs $(76,81,82)$. The study published by Capoccia et al. (83) ascribed a potential role of MIST1 in ER stress occurring in PCs. By transcriptome comparison between day-3 LPS-treated PCs obtained from Bhlha15 ${ }^{-1-}$ and WT mice, they found among the 218 differentially expressed genes specific functional annotations for endoplasmic reticulum and molecules transport. PCs associated with the small intestine have shown dilated and unorganized rough ER supporting the fact that MIST1 plays a critical role in ER stress despite its lack of involvement in PC differentiation (83).

In mice, the expression of Bhlha15 like $X b p 1$ is strongly induced in PCs compared to NBCs, MBCs and GC B cells (83,

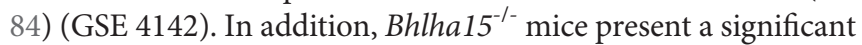
decrease of specific antibodies secretion in the serum 7 days after immunization (84). Overall, MIST1 and its respective functions have only been studied in the late stages of PC differentiation. Our RNA-seq data give a more precise picture on the regulation of BHLHA15 expression during normal human B cell differentiation and notably by showing an expression as soon as day-4 of the culture (Figure 3B), prompting for further studies about its function in ER-stress and UPR management during $B$ cell differentiation.

\section{USING B CELL DIFFERENTIATION MECHANISMS TO IMPROVE IMMUNOGLOBULIN PRODUCTION}

Production of recombinant protein has been well studied for the past few decades and research continues to constantly improve this engineered production. Among recombinant proteins, monoclonal antibodies (mAbs) production reports largely to the pharmaceutical industry. The first industrialized $\mathrm{mAb}$ was approved in 1997 and used for non-hodgkin's lymphoma patients. Rituxan ${ }^{\circledR}$, better known as Rituximab, was employed to recognize CD20 on B cells as an antigen. Almost 80 approved therapeutic mAbs were developed since, such as Humira ${ }^{\circledR}$ (Adalimumab/anti-TNF $\alpha$ ), Xolair ${ }^{\circledR}$ (Omalizumab/anti-IgE), Opdivo $^{\circledR}$ (Nivolumab/blocks PD-L1 binding to PD-1 and PD-2) or more recently Sarclisa ${ }^{\circledR}$ (Isatuximab/anti-CD38) and Imfinzi ${ }^{\circledR}$ (Durvalumab/blocks PD-L1 binding to PD-1 and CD80).
Each of them involved an intensive work mainly focused on how to efficiently increase mAb productivity (mAb titer and quality), a major concern in industrial settings.

Chinese Hamster Ovary ( $\mathrm{CHO}$ ) cells are the main producing cell line for engineered monoclonal antibody production. $\mathrm{CHO}$ cells are easy to manipulate and enable post-translational modifications important for Igs functions, such as glycosylation. Production is organized as (i) $\mathrm{CHO}$ cell line generation, consisting in the development of the vector for recombinant protein expression and its transfection into $\mathrm{CHO}$ cells, (ii) selection/purification of clones which integrated the vector, (iii) large scale bioproduction and (iv) final formulation to appropriately administrate $\mathrm{mAbs}$ into the patient. Continuous productivity improvement could be achieved by modifying cell culture conditions (85-87) and editing genes involved in protein translation, folding and secretion.

Massive production of recombinant proteins in $\mathrm{CHO}$ cells leads to an important ER stress requiring control to attain a production with high stability and quality. Uncontrolled ER stress generates less secreted proteins (mainly due to apoptosis of overstressed clones), but can be regulated by inducing autophagy (88). It also leads to a final product of poor quality (aggregates and subvisible particles coming from protein folding and assembly dysfunctions) (89), which, for the latter, represents issues for further clinical use (90). Hence, recent works proposed to control factors involved in the UPR pathway since some of them were described as able to monitor and control ER stress during Ig production. For instance, Talbot et al. (91) proposed to monitor ER stress in order to control aggregates concentration into the final product. To this end, they used two different culture conditions based on the presence or absence of specific nutrients for production of two different Ig subtypes. The deprivation condition induced a higher and earlier ER stress. The increase in the relative gene expression of several UPR-specific genes was assessed throughout culture and revealed a specific signature assigned to each Ig subtype and culture condition. Using this signature to monitor cell cultures, the authors obtained a significant decrease in aggregates and subvisible particles for IgG1 mAbs, unlike what was observed for IgG2 mAbs. In the case of IgG1 production, HSPA5 was induced later than for IgG2 while DERL3, an ER-associated degradation (ERAD)-specific gene which helps for un/misfolded protein degradation (9294) is induced earlier. This protected cells from overwhelmed UPR and allowed an extended time of culture. With the support of other studies, detailing ER biomarkers profiling during of CHO cell lines culture (95-97), they finally proposed to include a UPR genes signature to the quality parameters of mAbs production, providing culture conditions labelled as "ER stress under control". As an example, HERPUD1, another ERADspecific gene, is described as an early indicator of ER stress response $(96,97)$ and then could be used to predict production efficiency and stability. Interestingly, this gene is included in the cluster 2 of our study, indicating that it is an early UPR marker during the $\mathrm{B}$ cell differentiation process. Hence, our RNA-seq dataset supports conclusions of published data (95-97) and provides new potential factors to detect i) when ER stress is 
precociously managed, with genes such as VCP or MBTPS2 (both in cluster 2), and ii) UPR intensity during culture of high recombinant protein expressing cell lines with SYVN1, SSR1, DERL1, DERL2, MBTPS1 or WFS1 (all included in cluster 4).

The UPR activation is cell line-dependent but appears to be also clone-dependent. In fact, producing high-proliferative clones with high quality specificities is possible but relays on their proper ability to activate UPR and to escape from apoptosis. Therefore, a clonal selection process is necessary to select for clones with the best performance in terms of mAb titers, cell mass and viability. To this aim, UPR can be monitored with different UPR-inducible systems in $\mathrm{CHO}$ cells by (i) using promoters containing all three UPR responsive elements (UPRE, ERSE, and ACGT) (98), (ii) using native promoters of ER-stress induced factors such as $\mathrm{BiP}$ (99) or (iii) using a fluorescent reporter which produce specific fluorescence based on XBP-1 splicing by activated IRE1 $\alpha$ (96). Although those systems allow for selection of clones with the best performance, Poulain et al. (100) showed recently that during selection, the lower the expression of the protein of interest is in a pool of cells, the higher will be the frequency of clones with high productivity in this pool. To show this, they transduced a $\mathrm{CHO}$
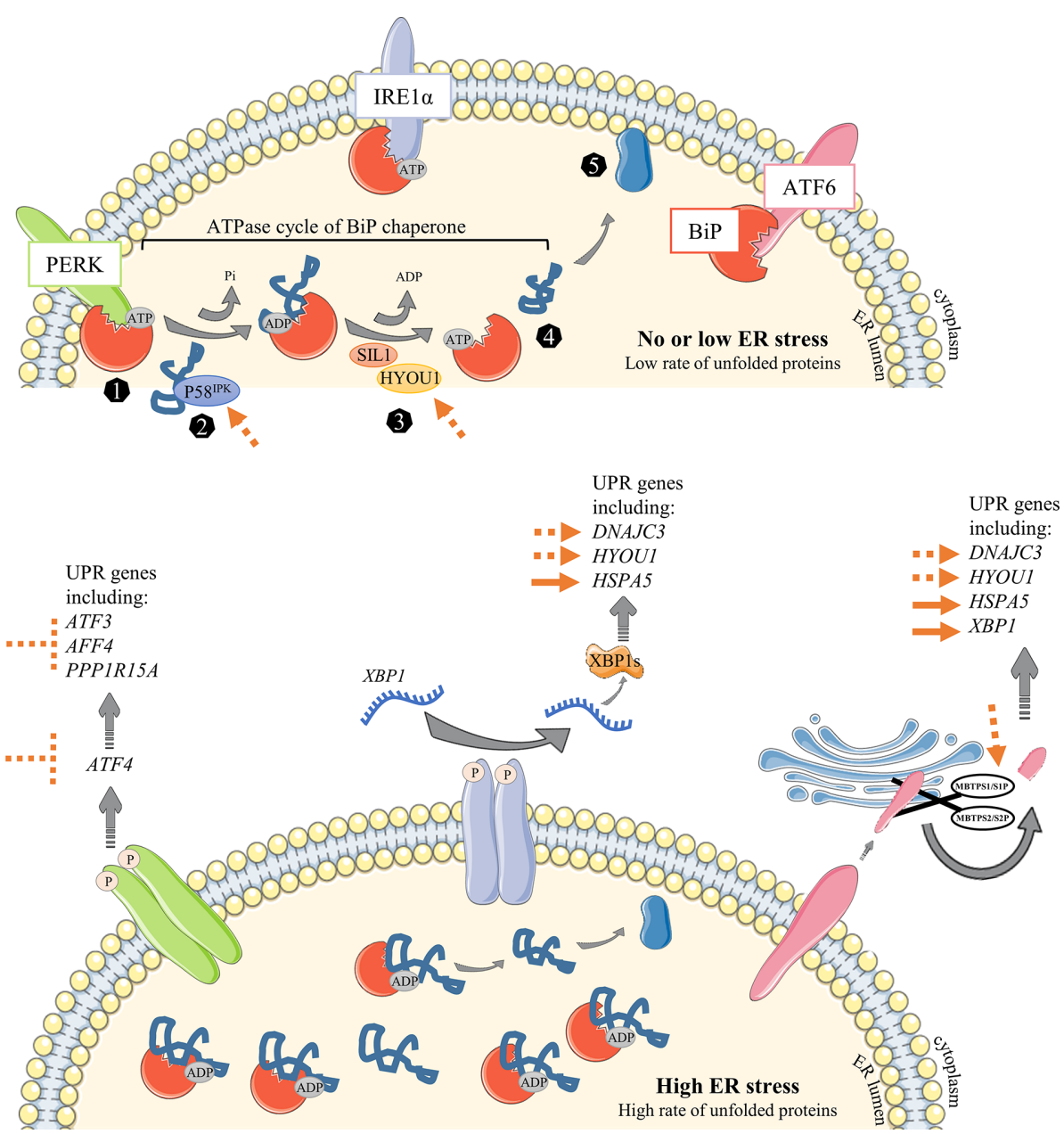

FIGURE 5 | Overview of known or suggested strategies to improve lg production in CHO cells. In the first steps of NBC activation, a low rate of proteins is processed into the ER leading to no or negligible stress conditions (upper panel). When cells undergo the following steps of differentiation that will result in the generation of highly-producing secreted lg PBs/PCs, mass of their ER is getting bigger and associated with an important stress. Unfolded Protein Response is then engaged to cope with the increasing amount of proteins in the ER. (1) The ER-resident chaperone BiP binds to unfolded and misfolded proteins and consequently releases the sequestrated IRE1 $\alpha$, PERK and ATF6 ER sensors, leading to their activation following (i) dimerization and auto-phosphorylation of IRE1 $\alpha$ and PERK elements or (ii) MBTPS1/S1P and MBTPS2/S2P - mediated cleavage of ATF6 $\alpha$ in the Golgi apparatus. (2) DnaJ family members such as P58 $8^{\text {PKK }}$ (encoded by DNAJC3) bind directly to unfolded and misfolded proteins to guide their transfer onto an ATP-bound BiP. Given the ATPase activity of BiP, an inorganic phosphate (Pi) is instantly released from BiP, leading to a conformational modification which stabilizes protein into the ADP-bound BiP (3). Thereafter, nucleotide-exchange factors (NEFs) such as SIL1 and HYOU1 facilitate the release of ADP from BiP and the rebinding of ATP. 4-5) As a consequence, client is released and then processed to be secreted outside of the cell. The main strategies already proposed to improve lg production in $\mathrm{CHO}$ cells are represented as full orange arrows. The strategies discussed in this review are represented as repressive or permissive dotted orange arrows. 
cell line containing an inducible expression system called cumate-gene switch with an inducible plasmid containing the gene of interest. This system allowed to study the impact of highversus low-expressing ones on final productivity. Therefore, reducing expression of recombinant proteins in $\mathrm{CHO}$ cells combined with selection of clones with higher capacities to deploy UPR, increases final recombinant protein titers and stability.

Decreasing ER stress during recombinant protein production has been one of the main concerns in $\mathrm{mAb}$ research since a few years. Therefore, controlling ER stress could represent a complementary aspect to the monitoring one. Work mainly focused on UPR-specific genes activation has been successfully done with factors such as IRE1 $\alpha(101), \operatorname{BiP}(102,103)$ or XBP-1 (104). PDIs (protein disulfite isomerases) which are upregulated during Ig production (such as PDIA5 and PDIA6 in cluster 4; Figure 3A) have also been shown to increase the protein secretion rate in $\mathrm{CHO}$ cells when overexpressed $(105,106)$.

As previously described in this review, BiP, XBP-1, IRE1 $\alpha$ and PDI are part of the cluster 4 in the dataset. Importantly, many other factors whose expression follows cluster 4 pattern are UPR sensors. Among them, P58 ${ }^{\mathrm{IPK}}$, MIST1 (both described in chapter 2), DERL1, WFS1, or even MBTPS1/S1P (Figure 5) could represent new targets to improve ER stress response during the production of mAbs. As previously shown, some pathways relative to ER stress responses are engaged very early after B cell activation, as shown by the cluster 2 in Figure 3A. Therefore, it would be advantageous to study genes from cluster 2 such as DDRGK1 (UFBP1 protein, described in chapter 2), PIGBOS1, HERPUD1, $D C T N 1, M B T P S 2 / S 2 P$ or ERO1A in order to increase the number of potential novel engineering targets. HYOU1, whose expression pattern has been discussed in this review, could be another interesting target (Figure 5), since its overexpression was shown to improve ER stress responses in liver cells from obese diabetic mice (74) or neurons under hypoxia $(72,73)$.

Nonetheless, inhibiting UPR suppressors such as ATF6 $\beta$ (107) could also represent an alternative way to increase mAbs productivity. Our analysis identifies DNAJB9 from cluster 4 as a potential new target since it acts by inhibiting activation of IRE1 $\alpha$ (108). Moreover, playing with PERK signaling could offer new strategies to improve productivity. Thus, the control of PERK downstream targets such as ATF3, DDIT3 or directly ATF4 or EIF2AK3 in CHO cells can protect cells from apoptosis (Figure 5). In accordance with our hypothesis, Roy et al. (96) observed a PERK inhibition feedback coupled with IRE1 $\alpha$

\section{REFERENCES}

1. Shapiro-Shelef M, Calame K. Regulation of Plasma-Cell Development. Nat Rev Immunol (2005) 5:230-42. doi: 10.1038/nri1572

2. Victora GD, Schwickert TA, Fooksman DR, Kamphorst AO, MeyerHermann M, Dustin ML, et al. Germinal Center Dynamics Revealed by Multiphoton Microscopy With a Photoactivatable Fluorescent Reporter. Cell (2010) 143:592-605. doi: 10.1016/j.cell.2010.10.032

3. De Silva NS, Klein U. Dynamics of B Cells in Germinal Centres. Nat Rev Immunol (2015) 15:137-48. doi: 10.1038/nri3804

4. Linterman MA, Beaton L, Yu D, Ramiscal RR, Srivastava M, Hogan JJ, et al. IL-21 Acts Directly on B Cells to Regulate Bcl-6 Expression and activation in cells with high levels of IgG secretion after several days of culture and argued that a mechanism may exists in PCs to decrease apoptosis risk over production time.

\section{CONCLUSION}

The model used in our laboratory facilitates the study of B cell development from NBCs to the plasmablast stage and allows to visualize at molecular level any modifications occurring either early or late during the maturation process $(6-8,109-111)$. Indeed, this paper brings new elements concerning the regulation of PERK and some factors that could have an impact on the productivity of mAbs. PERK regulation is poorly studied in B cells and our present study merges RNAsequencing with already published data regarding ER stress response in other cell types to unveil new mechanisms that need to be further studied in B cells. Additionally, despite the fact that research in mAbs engineering has been intensive over the past decades, here we have opened up new perspectives for the optimization of mAbs production.

\section{AUTHOR CONTRIBUTIONS}

ML performed the literature search, wrote and revised the manuscript, designed the figures and analysed the clusters with the DAVID bio-informatic tool. FC analysed the RNAsequencing dataset, generated heatmaps and revised the manuscript. GC and TF revised the manuscript. All authors contributed to the article and approved the submitted version.

\section{FUNDING}

This study was funded by Agence Nationale de la Recherche (ANR) number: ANR-19-CE15-0020-01.

\section{SUPPLEMENTARY MATERIAL}

The Supplementary Material for this article can be found online at: https://www.frontiersin.org/articles/10.3389/fimmu.2021. 671998/full\#supplementary-material

Germinal Center Responses. J Exp Med (2010) 207:353-63. doi: 10.1084/ jem. 20091738

5. Laidlaw BJ, Cyster JG. Transcriptional Regulation of Memory B Cell Differentiation. Nat Rev Immunol (2020) 21:209-20. doi: 10.1038/s41577-020-00446-2

6. Le Gallou S, Caron G, Delaloy C, Rossille D, Tarte K, Fest T. IL-2 Requirement for Human Plasma Cell Generation: Coupling Differentiation and Proliferation by Enhancing MAPK-ERK Signaling. J Immunol (2012) 189:161-73. doi: 10.4049/jimmunol.1200301

7. Pignarre A, Chatonnet F, Caron G, Haas M, Desmots-Loyer F, Fest T. Plasmablasts Derive From CD23-Negative Activated B Cells After the Extinction of IL-4/STAT6 Signaling and IRF4 Induction. Blood (2020) 137:1166-80. doi: 10.1182/blood.2020005083 
8. Caron G, Hussein M, Kulis M, Delaloy C, Chatonnet F, Pignarre A, et al. Cell-Cycle-Dependent Reconfiguration of the DNA Methylome During Terminal Differentiation of Human B Cells Into Plasma Cells. Cell Rep (2015) 13:1059-71. doi: 10.1016/j.celrep.2015.09.051

9. Kassambara $A$, Rème $T$, Jourdan $M$, Fest $T$, Hose $D$, Tarte $K$, et al. GenomicScape: An Easy-to-Use Web Tool for Gene Expression Data Analysis. Application to Investigate the Molecular Events in the Differentiation of B Cells Into Plasma Cells. PloS Comput Biol (2015) 11: e1004077. doi: 10.1371/journal.pcbi.1004077

10. Jourdan M, Cren M, Robert N, Bolloré K, Fest T, Duperray C, et al. IL-6 Supports the Generation of Human Long-Lived Plasma Cells in Combination With Either APRIL or Stromal Cell-Soluble Factors. Leukemia (2014) 28:1647-56. doi: 10.1038/leu.2014.61

11. Tagliavacca L, Anelli T, Fagioli C, Mezghrani A, Ruffato E, Sitia R. The Making of a Professional Secretory Cell: Architectural and Functional Changes in the ER During B Lymphocyte Plasma Cell Differentiation. Biol Chem (2003) 384:1273-7. doi: 10.1515/BC.2003.141

12. Lam WY, Bhattacharya D. Metabolic Links Between Plasma Cell Survival, Secretion, and Stress. Trends Immunol (2018) 39:19-27. doi: 10.1016/ j.it.2017.08.007

13. Todd DJ, Lee A-H, Glimcher LH. The Endoplasmic Reticulum Stress Response in Immunity and Autoimmunity. Nat Rev Immunol (2008) 8:663-74. doi: 10.1038/nri2359

14. Brewer JW, Hendershot LM. Building an Antibody Factory: A Job for the Unfolded Protein Response. Nat Immunol (2005) 6:23-9. doi: 10.1038/ ni1149

15. Bertolotti A, Zhang Y, Hendershot LM, Harding HP, Ron D. Dynamic Interaction of $\mathrm{BiP}$ and ER Stress Transducers in the Unfolded-Protein Response. Nat Cell Biol (2000) 2:326-32. doi: 10.1038/35014014

16. Sou SN, Ilieva KM, Polizzi KM. Binding of Human BiP to the ER Stress Transducers IRE1 and PERK Requires ATP. Biochem Biophys Res Commun (2012) 420:473-8. doi: 10.1016/j.bbrc.2012.03.030

17. Lin HY, Masso-Welch P, Di YP, Cai JW, Shen JW, Subjeck JR. The 170-kDa Glucose-Regulated Stress Protein is an Endoplasmic Reticulum Protein That Binds Immunoglobulin. Mol Biol Cell (1993) 4:1109-19. doi: 10.1091/ mbc.4.11.1109

18. Kityk R, Kopp J, Mayer MP. Molecular Mechanism of J-Domain-Triggered ATP Hydrolysis by Hsp70 Chaperones. Mol Cell (2018) 69:227-37.e4. doi: 10.1016/j.molcel.2017.12.003

19. Misselwitz B, Staeck O, Rapoport TA. J Proteins Catalytically Activate Hsp70 Molecules to Trap a Wide Range of Peptide Sequences. Mol Cell (1998) 2:593-603. doi: 10.1016/S1097-2765(00)80158-6

20. Behnke J, Feige MJ, Hendershot LM. BiP and Its Nucleotide Exchange Factors Grp170 and Sil1: Mechanisms of Action and Biological Functions. J Mol Biol (2015) 427:1589-608. doi: 10.1016/j.jmb.2015.02.011

21. Bracher A, Verghese J. The Nucleotide Exchange Factors of Hsp70 Molecular Chaperones. Front Mol Biosci (2015) 2:48-56. doi: 10.3389/ fmolb. 2015.00010

22. Shen J, Chen X, Hendershot L, Prywes R. ER Stress Regulation of ATF6 Localization by Dissociation of BiP/GRP78 Binding and Unmasking of Golgi Localization Signals. Dev Cell (2002) 3:99-111. doi: 10.1016/S1534-5807(02) 00203-4

23. Haze K, Yoshida H, Yanagi H, Yura T, Mori K. Mammalian Transcription Factor ATF6 is Synthesized as a Transmembrane Protein and Activated by Proteolysis in Response to Endoplasmic Reticulum Stress. Mol Biol Cell (1999) 10:3787-99. doi: 10.1091/mbc.10.11.3787

24. Yoshida H, Matsui T, Yamamoto A, Okada T, Mori K. XBP1 mRNA Is Induced by ATF6 and Spliced by IRE1 in Response to ER Stress to Produce a Highly Active Transcription Factor. Cell (2001) 107:881-91. doi: 10.1016/ S0092-8674(01)00611-0

25. Chen X, Shen J, Prywes R. The Luminal Domain of ATF6 Senses Endoplasmic Reticulum (ER) Stress and Causes Translocation of ATF6 From the ER to the Golgi. J Biol Chem (2002) 277:13045-52. doi: 10.1074/ jbc.M110636200

26. Shen J, Prywes R. Dependence of Site-2 Protease Cleavage of ATF6 on Prior Site-1 Protease Digestion Is Determined by the Size of the Luminal Domain of ATF6. J Biol Chem (2004) 279:43046-51. doi: 10.1074/ jbc.M408466200
27. Shaffer AL, Lin K-I, Kuo TC, Yu X, Hurt EM, Rosenwald A, et al. Blimp-1 Orchestrates Plasma Cell Differentiation by Extinguishing the Mature B Cell Gene Expression Program. Immunity (2002) 17:51-62. doi: 10.1016/S10747613(02)00335-7

28. Shaffer AL, Shapiro-Shelef M, Iwakoshi NN, Lee A-H, Qian S-B, Zhao H, et al. XBP1, Downstream of Blimp-1, Expands the Secretory Apparatus and Other Organelles, and Increases Protein Synthesis in Plasma Cell Differentiation. Immunity (2004) 21:81-93. doi: 10.1016/j.immuni.2004.06.010

29. Tellier J, Shi W, Minnich M, Liao Y, Crawford S, Smyth GK, et al. Blimp-1 Controls Plasma Cell Function Through the Regulation of Immunoglobulin Secretion and the Unfolded Protein Response. Nat Immunol (2016) 17:32330. doi: $10.1038 /$ ni.3348

30. Shimobayashi M, Hall MN. Making New Contacts: The mTOR Network in Metabolism and Signalling Crosstalk. Nat Rev Mol Cell Biol (2014) 15:15562. doi: $10.1038 / \mathrm{nrm} 3757$

31. Iwata TN, Ramírez JA, Tsang M, Park H, Margineantu DH, Hockenbery DM, et al. Conditional Disruption of Raptor Reveals an Essential Role for mTORC1 in B Cell Development, Survival, and Metabolism. J Immunol (2016) 197:2250-60. doi: 10.4049/jimmunol.1600492

32. Li B, Li Z, Wang P, Huang Q, Xu L, He R, et al. Mammalian Target of Rapamycin Complex 1 Signalling is Essential for Germinal Centre Reaction. Immunology (2017) 152:276-86. doi: 10.1111/imm.12767

33. Benhamron S, Pattanayak SP, Berger M, Tirosh B. mTOR Activation Promotes Plasma Cell Differentiation and Bypasses XBP-1 for Immunoglobulin Secretion. Mol Cell Biol (2015) 35:153-66. doi: 10.1128/ MCB.01187-14

34. Jones DD, Gaudette BT, Wilmore JR, Chernova I, Bortnick A, Weiss BM, et al. mTOR has Distinct Functions in Generating Versus Sustaining Humoral Immunity. J Clin Invest (2016) 126:4250-61. doi: 10.1172/JCI86504

35. Gaudette BT, Jones DD, Bortnick A, Argon Y, Allman D. mTORC1 Coordinates an Immediate Unfolded Protein Response-Related Transcriptome in Activated B Cells Preceding Antibody Secretion. Nat Commun (2020) 11:723. doi: 10.1038/s41467-019-14032-1

36. Harding HP, Zeng H, Zhang Y, Jungries R, Chung P, Plesken $\mathrm{H}$, et al. Diabetes Mellitus and Exocrine Pancreatic Dysfunction in Perk-/- Mice Reveals a Role for Translational Control in Secretory Cell Survival. Mol Cell (2001) 7:1153-63. doi: 10.1016/S1097-2765(01)00264-7

37. Zhang W, Feng D, Li Y, Iida K, McGrath B, Cavener DR. PERK EIF2AK3 Control of Pancreatic $\beta$ Cell Differentiation and Proliferation is Required for Postnatal Glucose Homeostasis. Cell Metab (2006) 4:491-7. doi: 10.1016/ j.cmet.2006.11.002

38. Sowers CR, Wang R, Bourne RA, McGrath BC, Hu J, Bevilacqua SC, et al. The Protein Kinase PERK/EIF2AK3 Regulates Proinsulin Processing Not Via Protein Synthesis But by Controlling Endoplasmic Reticulum Chaperones. J Biol Chem (2018) 293:5134-49. doi: 10.1074/jbc.M117.813790

39. Hisanaga S, Miyake M, Taniuchi S, Oyadomari M, Morimoto M, Sato R, et al. PERK-Mediated Translational Control is Required for Collagen Secretion in Chondrocytes. Sci Rep (2018) 8:773. doi: 10.1038/s41598-01719052-9

40. Zhang K, Wong HN, Song B, Miller CN, Scheuner D, Kaufman RJ. The Unfolded Protein Response Sensor IRE1 $\alpha$ is Required At 2 Distinct Steps in B Cell Lymphopoiesis. J Clin Invest (2005) 115:268-81. doi: 10.1172/ JCI200521848

41. Gass JN, Jiang H-Y, Wek RC, Brewer JW. The Unfolded Protein Response of B-lymphocytes: PERK-Independent Development of Antibody-Secreting Cells. Mol Immunol (2008) 45:1035-43. doi: 10.1016/j.molimm.2007.07.029

42. Ma Y, Shimizu Y, Mann MJ, Jin Y, Hendershot LM. Plasma Cell Differentiation Initiates a Limited ER Stress Response by Specifically Suppressing the PERK-dependent Branch of the Unfolded Protein Response. Cell Stress Chaperones (2010) 15:281-93. doi: 10.1007/s12192009-0142-9

43. Liu J, Wang Y, Song L, Zeng L, Yi W, Liu T, et al. A Critical Role of DDRGK1 in Endoplasmic Reticulum Homoeostasis Via Regulation of IRE1 $\alpha$ Stability. Nat Commun (2017) 8:14186. doi: 10.1038/ncomms14186

44. Zhu H, Bhatt B, Sivaprakasam S, Cai Y, Liu S, Kodeboyina SK, et al. Ufbp1 Promotes Plasma Cell Development and ER Expansion by Modulating Distinct Branches of UPR. Nat Commun (2019) 10:1084. doi: 10.1038/ s41467-019-08908-5 
45. Yan W, Frank CL, Korth MJ, Sopher BL, Novoa I, Ron D, et al. Control of PERK eIF2 Kinase Activity by the Endoplasmic Reticulum Stress-Induced Molecular Chaperone P58IPK. Proc Natl Acad Sci (2002) 99:15920-5. doi: 10.1073/pnas.252341799

46. van Huizen R, Martindale JL, Gorospe M, Holbrook NJ. P58IPK, a Novel Endoplasmic Reticulum Stress-Inducible Protein and Potential Negative Regulator of eIF2 $\alpha$ Signaling. J Biol Chem (2003) 278:15558-64. doi: $10.1074 /$ jbc.M212074200

47. Lee A-H, Iwakoshi NN, Glimcher LH. XBP-1 Regulates a Subset of Endoplasmic Reticulum Resident Chaperone Genes in the Unfolded Protein Response. Mol Cell Biol (2003) 23:7448-59. doi: 10.1128/ MCB.23.21.7448-7459.2003

48. Yamamoto K, Sato T, Matsui T, Sato M, Okada T, Yoshida H, et al. Transcriptional Induction of Mammalian ER Quality Control Proteins is Mediated by Single or Combined Action of ATF6 $\alpha$ and XBP1. Dev Cell (2007) 13:365-76. doi: 10.1016/j.devcel.2007.07.018

49. Wu J, Rutkowski DT, Dubois M, Swathirajan J, Saunders T, Wang J, et al. ATF6 $\alpha$ Optimizes Long-Term Endoplasmic Reticulum Function to Protect Cells From Chronic Stress. Dev Cell (2007) 13:351-64. doi: 10.1016/ j.devcel.2007.07.005

50. Roobol A, Roobol J, Bastide A, Knight JRP, Willis AE, Smales CM. p58IPK is an Inhibitor of the eIF2 $\alpha$ Kinase GCN2 and its Localization and Expression Underpin Protein Synthesis and ER Processing Capacity. Biochem J (2015) 465:213-25. doi: 10.1042/BJ20140852

51. Capone V, Clemente E, Restelli E, Di Campli A, Sperduti S, Ornaghi F, et al. PERK Inhibition Attenuates the Abnormalities of the Secretory Pathway and the Increased Apoptotic Rate Induced by SIL1 Knockdown in HeLa Cells. Biochim Biophys Acta Mol Basis Dis (2018) 1864:3164-80. doi: 10.1016/ j.bbadis.2018.07.003

52. Ichhaporia VP, Sanford T, Howes J, Marion TN, Hendershot LM. Sill, a Nucleotide Exchange Factor for BiP, is Not Required for Antibody Assembly or Secretion. Mol Biol Cell (2015) 26:420-9. doi: 10.1091/mbc.E14-09-1392

53. Cocco M, Care MA, Saadi A, Al-Maskari M, Doody G, Tooze R. A Dichotomy of Gene Regulatory Associations During the Activated B-Cell to Plasmablast Transition. Life Sci Alliance (2020) 3:e202000654. doi: 10.26508/sa.202000654

54. Weitzmann A, Volkmer J, Zimmermann R. The Nucleotide Exchange Factor Activity of Grp170 may Explain the Non-Lethal Phenotype of Loss of Sill Function in Man and Mouse. FEBS Lett (2006) 580:5237-40. doi: 10.1016/ j.febslet.2006.08.055

55. Zhao L, Rosales C, Seburn K, Ron D, Ackerman SL. Alteration of the Unfolded Protein Response Modifies Neurodegeneration in a Mouse Model of Marinesco-Sjögren Syndrome. Hum Mol Genet (2010) 19:25-35. doi: $10.1093 / \mathrm{hmg} / \mathrm{ddp} 464$

56. Kusaczuk M, Cechowska-Pasko M. Molecular Chaperone ORP150 in ER Stress-Related Diseases. Curr Pharm Des (2013) 19:2807-18. doi: 10.2174/ 1381612811319150016

57. Jung TW, Kyung EJ, Kim H-C, Shin YK, Lee SH, Park ES, et al. Protectin DX Ameliorates Hepatic Steatosis by Suppression of Endoplasmic Reticulum Stress Via AMPK-Induced ORP150 Expression. J Pharmacol Exp Ther (2018) 365:485-93. doi: 10.1124/jpet.117.246686

58. Jung TW, Park HS, Choi GH, Kim D, Ahn SH, Kim D-S, et al. Maresin 1 Attenuates Pro-Inflammatory Reactions and ER Stress in HUVECs Via PPAR $\alpha$-Mediated Pathway. Mol Cell Biochem (2018) 448:335-47. doi: 10.1007/s11010-018-3392-y

59. Zinszner H, Kuroda M, Wang X, Batchvarova N, Lightfoot RT, Remotti H, et al. CHOP is Implicated in Programmed Cell Death in Response to Impaired Function of the Endoplasmic Reticulum. Genes Dev (1998) 12:982-95. doi: 10.1101/gad.12.7.982

60. Harding HP, Zhang Y, Bertolotti A, Zeng H, Ron D. Perk Is Essential for Translational Regulation and Cell Survival During the Unfolded Protein Response. Mol Cell (2000) 5:897-904. doi: 10.1016/S1097-2765(00)80330-5

61. Lee A-H, Iwakoshi NN, Anderson KC, Glimcher LH. Proteasome Inhibitors Disrupt the Unfolded Protein Response in Myeloma Cells. Proc Natl Acad Sci (2003) 100:9946-51. doi: 10.1073/pnas.1334037100

62. Lu PD, Jousse C, Marciniak SJ, Zhang Y, Novoa I, Scheuner D, et al. Cytoprotection by Pre-Emptive Conditional Phosphorylation of Translation Initiation Factor 2. EMBO J (2004) 23:169-79. doi: 10.1038/sj.emboj.7600030
63. Lee A-H, Chu GC, Iwakoshi NN, Glimcher LH. XBP-1 is Required for Biogenesis of Cellular Secretory Machinery of Exocrine Glands. EMBO J (2005) 24:4368-80. doi: 10.1038/sj.emboj.7600903

64. Lin JH, Li H, Yasumura D, Cohen HR, Zhang C, Panning B, et al. IRE1 Signaling Affects Cell Fate During the Unfolded Protein Response. Science (2007) 318:944-9. doi: 10.1126/science.1146361

65. Han D, Upton J-P, Hagen A, Callahan J, Oakes SA, Papa FR. A Kinase Inhibitor Activates the IRE1 $\alpha$ RNase to Confer Cytoprotection Against ER Stress. Biochem Biophys Res Commun (2008) 365:777-83. doi: 10.1016/j.bbrc.2007.11.040

66. Lange PS, Chavez JC, Pinto JT, Coppola G, Sun C-W, Townes TM, et al. ATF4 is an Oxidative Stress-Inducible, Prodeath Transcription Factor in Neurons In Vitro and In Vivo. J Exp Med (2008) 205:1227-42. doi: 10.1084/ jem. 20071460

67. Tokutake Y, Yamada K, Hayashi S, Arai W, Watanabe T, Yonekura S. IRE1XBP1 Pathway of the Unfolded Protein Response is Required During Early Differentiation of C2C12 Myoblasts. Int J Mol Sci (2019) 21:182. doi: $10.3390 / \mathrm{ijms} 21010182$

68. McCarthy N, Dolgikh N, Logue S, Patterson JB, Zeng Q, Gorman AM, et al. The IRE1 and PERK Arms of the Unfolded Protein Response Promote Survival of Rhabdomyosarcoma Cells. Cancer Lett (2020) 490:76-88. doi: 10.1016/j.canlet.2020.07.009

69. Shi Z, Xu L, Xie H, Ouyang R, Ke Y, Zhou R, et al. Attenuation of Intermittent Hypoxia-Induced Apoptosis and Fibrosis in Pulmonary Tissues Via Suppression of ER Stress Activation. BMC Pulm Med (2020) 20:92. doi: 10.1186/s12890-020-1123-0

70. Zhou R, Ma Y, Tao Z, Qiu S, Gong Z, Tao L, et al. Melatonin Inhibits Glucose-Induced Apoptosis in Osteoblastic Cell Line Through PERK-eIF2 $\alpha$ ATF4 Pathway. Front Pharmacol (2020) 11:602307. doi: 10.3389/ fphar.2020.602307

71. Lin JH, Li H, Zhang Y, Ron D, Walter P. Divergent Effects of PERK and IRE1 Signaling on Cell Viability. PloS One (2009) 4:e4170. doi: 10.1371/ journal.pone. 0004170

72. Kuwabara K, Matsumoto M, Ikeda J, Hori O, Ogawa S, Maeda Y, et al. Purification and Characterization of a Novel Stress Protein, the $150-\mathrm{kDa}$ Oxygen-regulated Protein (ORP150), From Cultured Rat Astrocytes and Its Expression in Ischemic Mouse Brain. J Biol Chem (1996) 271:5025-32. doi: $10.1074 / j b c .271 .9 .5025$

73. Tamatani M, Matsuyama T, Yamaguchi A, Mitsuda N, Tsukamoto Y, Taniguchi M, et al. ORP150 Protects Against Hypoxia/Ischemia-Induced Neuronal Death. Nat Med (2001) 7:317-23. doi: 10.1038/85463

74. Nakatani Y, Kaneto H, Kawamori D, Yoshiuchi K, Hatazaki M, Matsuoka T, et al. Involvement of Endoplasmic Reticulum Stress in Insulin Resistance and Diabetes. J Biol Chem (2005) 280:847-51. doi: 10.1074/jbc.M411860200

75. Cox JS, Walter P. A Novel Mechanism for Regulating Activity of a Transcription Factor That Controls the Unfolded Protein Response. Cell (1996) 87:391-404. doi: 10.1016/S0092-8674(00)81360-4

76. Acosta-Alvear D, Zhou Y, Blais A, Tsikitis M, Lents NH, Arias C, et al. XBP1 Controls Diverse Cell Type- and Condition-Specific Transcriptional Regulatory Networks. Mol Cell (2007) 27:53-66. doi: 10.1016/ j.molcel.2007.06.011

77. Kowalik AS, Johnson CL, Chadi SA, Weston JY, Fazio EN, Pin CL. Mice Lacking the Transcription Factor Mist1 Exhibit an Altered Stress Response and Increased Sensitivity to Caerulein-Induced Pancreatitis. Am J Physiol Gastrointest Liver Physiol (2007) 292:G1123-32. doi: 10.1152/ ajpgi.00512.2006

78. Alahari S, Mehmood R, Johnson CL, Pin CL. The Absence of MIST1 Leads to Increased Ethanol Sensitivity and Decreased Activity of the Unfolded Protein Response in Mouse Pancreatic Acinar Cells. PloS One (2011) 6: e28863. doi: 10.1371 /journal.pone. 0028863

79. Hess DA, Strelau KM, Karki A, Jiang M, Azevedo-Pouly AC, Lee A-H, et al. MIST1 Links Secretion and Stress as Both Target and Regulator of the Unfolded Protein Response. Mol Cell Biol (2016) 36:2931-44. doi: 10.1128/ MCB.00366-16

80. Lo H-YG, Jin RU, Sibbel G, Liu D, Karki A, Joens MS, et al. A Single Transcription Factor is Sufficient to Induce and Maintain Secretory Cell Architecture. Genes Dev (2017) 31:154-71. doi: 10.1101/gad.285684.116

81. Huh WJ, Esen E, Geahlen JH, Bredemeyer AJ, Lee A-H, Shi G, et al. XBP1 Controls Maturation of Gastric Zymogenic Cells by Induction of MIST1 and 
Expansion of the Rough Endoplasmic Reticulum. Gastroenterology (2010) 139:2038-49. doi: 10.1053/j.gastro.2010.08.050

82. Metzler MA, Venkatesh SG, Lakshmanan J, Carenbauer AL, Perez SM, Andres SA, et al. A Systems Biology Approach Identifies a Regulatory Network in Parotid Acinar Cell Terminal Differentiation. PloS One (2015) 10:e0125153. doi: 10.1371/journal.pone.0125153

83. Capoccia BJ, Lennerz JKM, Bredemeyer AJ, Klco JM, Frater JL, Mills JC. Transcription Factor MIST1 in Terminal Differentiation of Mouse and Human Plasma Cells. Physiol Genomics (2011) 43:174-86. doi: 10.1152/ physiolgenomics.00084.2010

84. Bhattacharya D, Cheah MT, Franco CB, Hosen N, Pin CL, Sha WC, et al. Transcriptional Profiling of Antigen-Dependent Murine B Cell Differentiation and Memory Formation. J Immunol (2007) 179:6808-19. doi: 10.4049/jimmunol.179.10.6808

85. Sandadi S, Ensari S, Kearns B. Heuristic Optimization of Antibody Production by Chinese Hamster Ovary Cells. Biotechnol Prog (2005) 21:1537-42. doi: 10.1021/bp0501266

86. Kelly PS, Alarcon Miguez A, Alves C, Barron N. From Media to Mitochondria-Rewiring Cellular Energy Metabolism of Chinese Hamster Ovary Cells for the Enhanced Production of Biopharmaceuticals. Curr Opin Chem Eng (2018) 22:71-80. doi: 10.1016/j.coche.2018.08.009

87. Yin B, Wang Q, Chung C-Y, Ren X, Bhattacharya R, Yarema KJ, et al. Butyrated ManNAc Analog Improves Protein Expression in Chinese Hamster Ovary Cells. Biotechnol Bioeng (2018) 115:1531-41. doi: 10.1002/ bit. 26560

88. Braasch K, Kryworuchko M, Piret JM. Autophagy-Inducing Peptide Increases CHO Cell Monoclonal Antibody Production in Batch and FedBatch Cultures. Biotechnol Bioeng (2021) 118:bit.27703. doi: 10.1002/ bit.27703

89. Ishii Y, Murakami J, Sasaki K, Tsukahara M, Wakamatsu K. Efficient Folding/Assembly in Chinese Hamster Ovary Cells is Critical for High Quality (Low Aggregate Content) of Secreted Trastuzumab as Well as for High Production: Stepwise Multivariate Regression Analyses. J Biosci Bioeng (2014) 118:223-30. doi: 10.1016/j.jbiosc.2014.01.013

90. Matucci A, Nencini F, Pratesi S, Maggi E, Vultaggio A. An Overview on Safety of Monoclonal Antibodies. Curr Opin Allergy Clin Immunol (2016) 16:576-81. doi: 10.1097/ACI.0000000000000315

91. Talbot NE, Mead EJ, Davies SA, Uddin S, Smales CM. Application of ER Stress Biomarkers to Predict Formulated Monoclonal Antibody Stability. Biotechnol J (2019) 14:1900024. doi: 10.1002/biot.201900024

92. Hiller MM, Finger A, Schweiger M, Wolf DH. ER Degradation of a Misfolded Luminal Protein by the Cytosolic Ubiquitin-Proteasome Pathway. Science (1996) 273:1725-8. doi: 10.1126/science.273.5282.1725

93. Oda Y, Okada T, Yoshida H, Kaufman RJ, Nagata K, Mori K. Derlin-2 and Derlin-3 are Regulated by the Mammalian Unfolded Protein Response and are Required for ER-associated Degradation. J Cell Biol (2006) 172:383-93. doi: $10.1083 /$ jcb.200507057

94. Belmont PJ, Chen WJ, San Pedro MN, Thuerauf DJ, Gellings Lowe N, Gude $\mathrm{N}$, et al. Roles for Endoplasmic Reticulum-Associated Degradation and the Novel Endoplasmic Reticulum Stress Response Gene Derlin-3 in the Ischemic Heart. Circ Res (2010) 106:307-16. doi: 10.1161/ CIRCRESAHA.109.203901

95. Prashad K, Mehra S. Dynamics of Unfolded Protein Response in Recombinant CHO Cells. Cytotechnology (2015) 67:237-54. doi: 10.1007/ s10616-013-9678-8

96. Roy G, Zhang S, Li L, Higham E, Wu H, Marelli M, et al. Development of a Fluorescent Reporter System for Monitoring ER Stress in Chinese Hamster Ovary Cells and its Application for Therapeutic Protein Production. PloS One (2017) 12:e0183694. doi: 10.1371/journal.pone.0183694

97. Maldonado-Agurto R, Dickson AJ. Multiplexed Digital mRNA Expression Analysis Profiles System-Wide Changes in mRNA Abundance and Responsiveness of UPR-Specific Gene Expression Changes During Batch Culture of Recombinant Chinese Hamster Ovary Cells. Biotechnol J (2018) 13:1700429. doi: 10.1002/biot.201700429
98. Du Z, Treiber D, McCoy RE, Miller AK, Han M, He F, et al. Non-Invasive UPR Monitoring System and its Applications in CHO Production Cultures. Biotechnol Bioeng (2013) 110:2184-94. doi: 10.1002/bit.24877

99. Kober L, Zehe C, Bode J. Development of a Novel ER Stress Based Selection System for the Isolation of Highly Productive Clones. Biotechnol Bioeng (2012) 109:2599-611. doi: 10.1002/bit.24527

100. Poulain A, Mullick A, Massie B, Durocher Y. Reducing Recombinant Protein Expression During CHO Pool Selection Enhances Frequency of HighProducing Cells. J Biotechnol (2019) 296:32-41. doi: 10.1016/ j.jbiotec.2019.03.009

101. Koskela EV, Gonzalez Salcedo A, Piirainen MA, Iivonen HA, Salminen H, Frey AD. Mining Data From Plasma Cell Differentiation Identified Novel Genes for Engineering of a Yeast Antibody Factory. Front Bioeng Biotechnol (2020) 8:255. doi: 10.3389/fbioe.2020.00255

102. Damasceno LM, Anderson KA, Ritter G, Cregg JM, Old LJ, Batt CA. Cooverexpression of Chaperones for Enhanced Secretion of a Single-Chain Antibody Fragment in Pichia Pastoris. Appl Microbiol Biotechnol (2007) 74:381-9. doi: 10.1007/s00253-006-0652-7

103. Ha TK, Hansen AH, Kildegaard HF, Lee GM. BiP Inducer X: An ER Stress Inhibitor for Enhancing Recombinant Antibody Production in CHO Cell Culture. Biotechnol J (2019) 14:1900130. doi: 10.1002/biot.201900130

104. Tigges M, Fussenegger M. Xbp1-based Engineering of Secretory Capacity Enhances the Productivity of Chinese Hamster Ovary Cells. Metab Eng (2006) 8:264-72. doi: 10.1016/j.ymben.2006.01.006

105. Mohan C, Park SH, Chung JY, Lee GM. Effect of Doxycycline-Regulated Protein Disulfide Isomerase Expression on the Specific Productivity of Recombinant CHO Cells: Thrombopoietin and Antibody. Biotechnol Bioeng (2007) 98:611-5. doi: 10.1002/bit.21453

106. Borth N, Mattanovich D, Kunert R, Katinger H. Effect of Increased Expression of Protein Disulfide Isomerase and Heavy Chain Binding Protein on Antibody Secretion in a Recombinant CHO Cell Line. Biotechnol Prog (2008) 21:106-11. doi: 10.1021/bp0498241

107. Pieper LA, Strotbek M, Wenger T, Olayioye MA, Hausser A. ATF6ß-Based Fine-Tuning of the Unfolded Protein Response Enhances Therapeutic Antibody Productivity of Chinese Hamster Ovary Cells: ATF6 $\beta$-Based CHO Cell Engineering. Biotechnol Bioeng (2017) 114:1310-8. doi: 10.1002/ bit.26263

108. Amin-Wetzel N, Saunders RA, Kamphuis MJ, Rato C, Preissler S, Harding HP, et al. A J-Protein Co-Chaperone Recruits Bip to Monomerize IRE1 and Repress the Unfolded Protein Response. Cell (2017) 171:1625-37.e13. doi: 10.1016/j.cell.2017.10.040

109. Dalloul I, Boyer F, Dalloul Z, Pignarre A, Caron G, Fest T, et al. Locus Suicide Recombination Actively Occurs on the Functionally Rearranged IgH Allele in B-cells From Inflamed Human Lymphoid Tissues. PloS Genet (2019) 15: e1007721. doi: 10.1371/journal.pgen.1007721

110. Jourdan M, Caraux A, Caron G, Robert N, Fiol G, Rème T, et al. Characterization of a Transitional Preplasmablast Population in the Process of Human B Cell to Plasma Cell Differentiation. J Immunol (2011) 187:3931-41. doi: 10.4049/jimmunol.1101230

111. Hipp N, Symington H, Pastoret C, Caron G, Monvoisin C, Tarte K, et al. IL-2 Imprints Human Naive B Cell Fate Towards Plasma Cell Through ERK/ ELK1-mediated BACH2 Repression. Nat Commun (2017) 8:1443. doi: 10.1038/s41467-017-01475-7

Conflict of Interest: The authors declare that the research was conducted in the absence of any commercial or financial relationships that could be construed as a potential conflict of interest.

Copyright $\odot 2021$ Lemarié, Chatonnet, Caron and Fest. This is an open-access article distributed under the terms of the Creative Commons Attribution License (CC BY). The use, distribution or reproduction in other forums is permitted, provided the original author(s) and the copyright owner(s) are credited and that the original publication in this journal is cited, in accordance with accepted academic practice. No use, distribution or reproduction is permitted which does not comply with these terms. 